\title{
Economic aspects of aged apple plantations in Hungary
}

\author{
Apáti, F. \& Felföldi, J. \\ Department of Farm Business Management, Faculty of Agricultural Economics and Rural Development, \\ Centre for Agricultural Sciences, University of Debrecen 138 Böszörményi St ., H-4032 Debrecen
}

Summary: Being competitive is a goal all over in the EU. Competition is free and getting closer among the competitors of the apple industry. In Hungary, one of the most important issues of apple industry has been what are the prospects for aged plantations, which account for $50 \%$ of crop land. Based on our results, $80 \%$ of those apple plantations on the down-grade yielding apple, the ones only for processing, do not meet the criteria of competitive production. For those plantations in better shape that yield $30-40$ t/ha, of which at least $20-30 \%$ are for fresh production, it can be profitable. Because of the future trend in technology and economy, however, even the latter ones can not be considered being competitive in the long run.

Key words: apple, aged plantation, yield, direct costs, profitability

\section{Introduction}

Apple production is the most significant industry of fruit production in Hungary. Yearly production of 1.1-1.2 million tonnes of apples accounted for about two-thirds of the total fruit production in the 1980 s. The change in economic and political status which happened at the beginning of the last decade, affected agriculture heavily, including apple production. The crisis featuring the apple industry in the middle 1990s has been left behind, starting a new developing stage while keeping its leader role in fruit production in Hungary.

The outstanding role of apple production is proven by the significant volume of labour applied and the monetary value of billions of assets tied up in the industry, while accounting for $8-10 \%$ of the total value of plant production in Hungary. Unfortunately, there was a decrease in the area under apple production and also in the total yield, a decrease which was considered up to $40 \%$ for total yield. This decrease was caused by aging plantations that give lower yields, parallel with unsatisfactory structure of varieties. (Kiss, 2003a)

Apple producers in Hungary have to face new challenges generated by the producer needs and the economic and technological environment. Therefore it is vital how they can adapt to changed market conditions and participate in the close competition. Competitiveness of the whole apple industry is influenced by the age structure of our plantations that show that about half of the apple plantations are over 20-25 years old; in other words, they are beyond their periods of high yield. For these plantations, the structure of crops and technology applied are out of date. Most of the produce is sold for processing, so the future competitiveness is questioned. At the same time, the share of production area is significant, so it is clear that they basically affect the tendency in the development of the industry on the whole.
We completely agree with the statement of Pethö (2006): "we have to accept that economic-and production policy fact that there is a periodic need to appraise each culture of production and define the conditions of updating."

The above mentioned facts were the inspiration to figure the outlook for those out of date, so called "aged apple plantations". Competitiveness is mainly determined by the efficiency of production; beyond that, quality, innovation, and consumer-centric attitude (Marosán, 2001), so it is vital to analyse the apple enterprise from the aspects of efficiency in the farm business.

In this study, we show those parameters by which running an aged apple plantation can not be competitive, and also those parameters by which producers of such plantations can make quick profits over a period of time. Using farm business data, we extrapolate future tendency for apple industry on the whole, based on national statistical data, on sizes and conditions of plantations.

\section{Materials and methods}

First of all, we have to define what an "aged plantation" is. An aged plantation is over 20-25 years old and the period of its high yields, parallel with the technological features such as medium vigorous M4 rootstock or rarely stong vigorous seedling rootstock, wide spacing with low density per hectare ( 100 to 666 trees per hectare). It is featured by training system with set of branches, modified spindle, and hedgerow, and by spacing from 10 by 10 meters up to 5 by 3 meters. The structure of varieties is dominated by 'Jonathan', followed by 'Golden Delicious' and 'Starking', 'Starkrimson' representing a small portion of the whole (Gonda, 2000). Such orchards were planted in the 1950-70s, so they are between 25 and 55 years of age. 
Competitiveness is determined by four factors, we focused only on quality and efficiency of production. Analysing efficiency, we highlighted profitability as one of the most important measures of the farm business. Data needed for analysis were provided by apple producer organisations. Economic data were based on the technological process, for which we systematically recorded the use of resources in physical terms. These technological data, given in physical terms were expressed in money value in our economic-model.

\section{Results}

\section{Fundamentals of production in Hungary}

The latest census of plantations was conducted by the Hungarian Central Statistical Office in 2001, therefore we had to use these authentic data, but we have made some corrections on the data about the age of the plantations, taking them as actualities.

In Hungary there are about 40,000 hectares of apple plantations, of which approximately 18,000 hectares $(45 \%)$ of the plantations are over 25 years old. These can be considered anachronistic. If we take into account other features of the fundamentals of production and not only the age of plantations, we can identify the next relationship. Apple orchards standing on M4 rootstock and seedling rootstock cover 16,900 hectares, orchards with density less than 400 trees per hectare cover 16,400 hectares, and with medium or poor condition cover 16,600 hectares, and apple orchards treated at lower level than the average cover 16,000 hectares. The similarity of these data points to the fact that each case relates to aged plantations characterized by poor technological levels and poor conditions. On the other hand, this confirms the correctness of criteria we used in the definition of aged plantation.

The point of this study is to associate statistical data at industry level with data at farm level, in order to estimate data which will help to arrive to an outlook for aged plantations. Considering the subjectiveness of the appraisal of plantation conditions, the average yields will be the base of drawing a parallel between data at industry and farm levels.

Table 1. Distribution of aged apple plantations by yield categories

\begin{tabular}{|c|c|c|}
\hline $\begin{array}{c}\text { Average yield } \\
\text { categories }(t / h a)\end{array}$ & $\begin{array}{l}\text { Area } \\
(\text { ha })\end{array}$ & $\begin{array}{c}\text { Percentage ratio } \\
(\%)\end{array}$ \\
\hline$<10$ & 2,766 & 15 \\
\hline $10-15$ & 2,034 & 11 \\
\hline $15-20$ & 3,297 & 19 \\
\hline $20-25$ & 4,374 & 24 \\
\hline $25-30$ & 2,269 & 13 \\
\hline $30-35$ & 1,601 & 9 \\
\hline $35-40$ & 0,576 & 3 \\
\hline$>40$ & 1,083 & 6 \\
\hline & 18,000 & 100 \\
\hline Total: & & \\
\hline
\end{tabular}

Source: KSH-Central Statistical Office, 2001
Table $I$ shows us that only $31 \%$ of aged plantations can produce reasonable average yield, namely yield of more then $25 \mathrm{t} / \mathrm{ha}$. The rest of two-thirds can produce only low average yields; moreover, $45 \%$ can not reach even 20 tha. Aside from the quality of produce, we can state that it is only one-third of aged plantations - about 5,500 hectares - that can be acceptable from the aspect of yielding.

Data by the Central Statistical Office have to be commented on. If we do the calculations using data by CSO, the physical volume of produce that came from those 18,000 hectares of aged plantations is about 400,000 tonnes of apple per year. Knowing the yearly apple production of $400,000-600,000$ tonnes in Hungary, it can be stated that the CSO data disfigure the yielding capacity of aged plantations, showing it higher than it actually is.

Table 2. Condition and treatment of aged apple plantations

\begin{tabular}{|c|c|c|}
\hline \multicolumn{3}{|c|}{ Condition } \\
\hline Category & Area (ha) & Percentage ratio $(\%)$ \\
\hline Poor & 4,689 & 26 \\
\hline Middle & 8,030 & 45 \\
\hline Good & 5,281 & 29 \\
\hline Total & 18,000 & 100 \\
\hline \multicolumn{3}{|c|}{ Treatment } \\
\hline Category & Area (ha) & Percentage ratio (\%) \\
\hline Untreated & 2.085 & 12 \\
\hline Poorly treated & 2,877 & 16 \\
\hline Moderately treated & 7,005 & 39 \\
\hline Suitably treated & 6,032 & 34 \\
\hline Total: & 18,000 & 100 \\
\hline
\end{tabular}

Source: KSH-Central Statistical Office, $200 \mathrm{l}$

According to statistics, it fits with the distribution by yielding categories that those plantations in good condition account for 5,300 hectares and suitably treated plantations account for 6,000 hectares (Table 2). Therefore it can be presumed that is the same 5,000-6,000 hectares for all those three aspects. This low share is supported by Szabó (2006) in a statement which says that most aged plantations are untreated (weeds, no pruning, no spraying etc.) and their produce hardly meets even the requirements of apple for processing purpose.

\section{Production efficiency}

Considering the complexity of production efficiency, here we focused on only one of its important elements: profitability. It needs to be highlighted that data presented here derive from a detailed analysis of farm business. In this study, we use a very simplified structure to show the results.

Simplifying the situation based on collected and analysed farm business data, we divided aged apple plantations into three main groups, which properly represent the real situation.

Variant "A" group includes plantations that are characterized by poor condition and use of input at low level, which allows them to give not more than 10-20 tonnes per hectare of average yield with quality for processing only. 
Variant "B" group includes plantations with the same product quality like the former group, but they have a bit better conditions and higher level of input use, which allows them to give 30-40 tonnes per hectare average yields.

Variant "C" group includes those plantations with reasonable yields providing $20-30 \%$ share of apples for fresh consumption.

Production costs for each group are shown in Table 3. Out of date plantations are featured by minimising use of inputs, which relates to their lower yielding capacity and product quality.

According to our survey, for variant "A" we took into consideration only those technological activities that were still essential to keep even though the low level of yields. So inputs are used for spraying 7-8 times per production period, weed control done by hand and by chemicals, which is once a year in general, small rate of nitrogenous fertilizer application such as $150-200 \mathrm{~kg} / \mathrm{ha}$, cultivation of ridge spacing (cutting, grasscrashing which are done 3-4 times a year), and for pruning and harvesting (loading and transportation).

For variant " $\mathrm{B}$ ", the level of input use is a bit higher, which is caused by more frequent spraying (10-11 times a year), higher rate of fertiliser application $(300-400 \mathrm{~kg} / \mathrm{ha}$ nitrogenphosphorus-potassium), as well as the increase in variable costs generated by higher yields. This higher level of output use is justified by the relatively good yielding capacity. Variant "C" differs from "B" in the number of spraying up to 12-13 times a year, using special fertilizers such as calcium, and in the higher labour costs caused by harvesting apple for fresh consumption. There is no storage cost or very low cost because the product is marketed right after harvest, maybe farmers keep it for some weeks as temporary storage.

Table 3. Direct costs for aged plantations

\begin{tabular}{|l|c|r|r|r|}
\hline DENOMINATION & M.u. & $\begin{array}{c}\text { variant } \\
\text {,A” }\end{array}$ & $\begin{array}{c}\text { variant } \\
\text { „B” }\end{array}$ & $\begin{array}{c}\text { variant } \\
\text { „C" }\end{array}$ \\
\hline Material costs & HUF per hectare & 97,000 & 139,000 & 219,000 \\
\hline Labour costs & HUF per hectare & 74,000 & 144,000 & 179,000 \\
\hline Machinery costs & HUF per hectare & 74,000 & 117,000 & 132,000 \\
\hline $\begin{array}{l}\text { Amortisation of } \\
\text { plantation }\end{array}$ & HUF per hectare & 0 & 0 & 0 \\
\hline Direct costs: & HUF per hectare & $\mathbf{2 4 5 , 0 0 0}$ & $\mathbf{4 0 0 , 0 0 0}$ & $\mathbf{5 3 0 , 0 0 0}$ \\
\hline
\end{tabular}

Analysing the structure of cost types we can state there is no significant difference between them when taking their percentage compound. Each case includes $35-40 \%$ of material costs, 25-30\% labour costs, and 25-30\% machinery costs. Implicitly, there is no amortisation left for such plantations. However, we calculated labour costs as completely paid handy work, the farmer and his family unpaid labour work was not considered.

On the whole, we can state that the rise in costs found variant "A" to "C" is caused by a higher level of plant protection and fertiliser application, as well as the additional harvesting cost incurred from producing higher yields.

Let us now review the profit making capacity of the variants (Table 4.). It is to be highlighted that overheads not connected directly to the performance of the enterprise were not considered. Therefore, the category computed is gross margin. For each variant data mentioned earlier in this study was used. Selling price for apples for processing was calculated by prices in the last five years and predicted price tendencies. Selling price for apple for fresh consumption was set at low level, so as to meet the product quality features such as out of date variety with small size, poorly coloured apples which has not a demanded in the market.

Table 4. Profit making by aged plantations

\begin{tabular}{|l|c|r|r|r|}
\hline DENOMINATION & M.u. & \multicolumn{1}{c|}{$\begin{array}{c}\text { variant } \\
\text {,A” }\end{array}$} & $\begin{array}{c}\text { variant } \\
\text {,B” }\end{array}$ & \multicolumn{1}{c|}{$\begin{array}{c}\text { variant } \\
\text { „C” }\end{array}$} \\
\hline Average yield & t/ha & 15.0 & 35.0 & 35.0 \\
\hline - apple for processing & $\%$ & 100.0 & 100.0 & 75.0 \\
\hline $\begin{array}{l}\text { - apple for fresh } \\
\text { consumption }\end{array}$ & $\%$ & 0.0 & 0.0 & 25.0 \\
\hline $\begin{array}{l}\text { Average selling price } \\
\text { - apple for processing }\end{array}$ & HUF/kg & 12.0 & 12.0 & 12.0 \\
\hline $\begin{array}{l}\text { - apple for fresh } \\
\text { consumption }\end{array}$ & HUF/kg & - & - & 40.0 \\
\hline Sales & HUF/ha & $\mathbf{1 8 0 , 0 0 0}$ & $\mathbf{4 2 0 , 0 0 0}$ & $\mathbf{6 6 5 , 0 0 0}$ \\
\hline Direct costs & HUF/ha & 245,000 & 400,000 & 530,000 \\
\hline Direct costs & HUF/kg & 16.3 & 11.4 & 15.1 \\
\hline Gross margin & HUF/ha & $\mathbf{- 6 5 , 0 0 0}$ & $\mathbf{2 0 , 0 0 0}$ & $\mathbf{1 3 5 , 0 0 0}$ \\
\hline $\begin{array}{l}\text { Rate of return on } \\
\text { direct costs }\end{array}$ & \% & -27.0 & 5.0 & 25.0 \\
\hline $\begin{array}{l}\text { Net Farm Income } \\
\text { (by enterprise) }\end{array}$ & HUF/ha & $\mathbf{9 , 0 0 0}$ & $\mathbf{1 6 4 , 0 0 0}$ & $\mathbf{3 1 4 , 0 0 0}$ \\
\hline
\end{tabular}

For variant "A", this is a low profit making capacity because at current price level, apple for processing can not be profitable. In our case, gross margin refers to profit or loss as a category expressing an enterprise performance. For variant "B", it is possible to make at least a small gross margin. But remember that overheads that would be in a loss making situation were not considered. So these plantations can be grouped as loss making ones in general, but sometimes favourable environment in a good year can make them profitable to a certain (minimum) extent. It is only variant " $\mathrm{C}$ ", which consists of plantations providing reasonable gross margin per hectare, due to the proportion of apple for fresh consumption only. As compared to up-to-date plantations producing for farms with reasonable market background, even this gross margin is much lower than those can make.

Since apple is produced mainly by private farms, farms with less than one hectare and based on part-time work of family labour which produce about $70 \%$ of total apple production (Erdészné, 2000), therefore it is justified to use net farm income. Computing net farm income, we assume that all manual work is done by family labour not paid by the farmer. It can be stated that variant "A" can hardly provide positive net farm income; therefore at the level of current prices for apple for processing, this yield of 15 tonnes per hectare is not enough to be profitable. Variant "B" can provide some net farm income, so we can presume that farmers 
running such plantations will continue apple production in default of alternative activity. It is to be pointed out that net farm income derived from variant " $\mathrm{B}$ " refers to 410 HUF per hour wage computed on the base of 400 hours per hectare labour work, which is higher than the national minimum wage in Hungary. Variant " $C$ " can provide even higher net farm income by which this refers to 650 HUF per hour wage computed on the base of 480 hours per hectare labour work.

\section{Conclusions and discussion}

Thereinafter we draw a parallel between data shown by Table 1. and Table 4., so as to extrapolate the outlook for the apple plantations based on macro- and micro level data on farm business.

Table l. Shows that two-thirds of inland aged plantations are characterized by low yields ( $10-25$ tonnes per hectare) and poor conditions, which are grouped into variant " $\mathrm{A}$ " in this study. Variant "A" covers some 12,500 hectares that are in a loss situation in today's economic environment.

The rest of the plantations with better conditions, covering 5,500 hectares can give 25-50 tonnes per hectare, which are grouped into variant " $\mathrm{B}$ " and " $\mathrm{C}$ ". In default of relevant statistical data, we presumed that variant " $\mathrm{B}$ " and variant " $C$ " cover 2,700 hectares and 2,800 hectares, respectively. So we can conclude that 2,700 hectares covered by variant"B" can provide some profit if the production is based on unpaid family labour. At the same time, 2,800 hectares covered by variant " $\mathrm{C}$ " can provide profit (with some $25 \%$ apple for fresh consumption out of the total apple production) even if the labour is paid by the farmer.

A world market forecast indicates that China, which produces one-third of the world apple production, can produce at low cost, so the Chinese can sell at a low price that will keep the price for apple for processing at a low level in Hungary too. (Saure, 2001). This tendency is justified by Ellinger (2001) who stated that China's share would increase in the future, since most plantations still have not produced.

Based on world market trends and our analysis, we conclude that 70 per cent of 18,000 hectares of aged apple plantations, which is variant " $\mathrm{A}$ " with 12,500 hectares, is not competitive even in short-term. Those plantations of variant "B" which are cultivated by unpaid family labour to be pruned, picked, etc., covering about 1,500 hectares, can make $100,000-200,000$ HUF of net farm income. This sum of income refers to some 400 HUF per hour wage, encouraging farmers to keep on running such plantations. On farms with plantations of variant " $\mathrm{C}$ " production would be sustained in middle-term, that is 4-8 year period in our opinion. Nevertheless, not even these ones can be sustained for longterm because of their biological limit.

Based on the results we expect some 13,000-14,000 hectares being cut over the next 3-4 years, while the rest of 4,000-5,000 hectares will be liquidated over the following 4-8 years. That will result in a decrease of $40-50 \%$ in the area for apple plantations during the next decade.
At the end of this study, there is at least one question left to be answered. Why were these plantations with trouble in profit making not liquidated in the past? The answer is that before joining the EU, there was a cyclical price for apple for processing, which was once in 3-4 years, and being helped with state subsidy, these plantations provided a reasonable profit that helped sustaining them. So, farmers resumed production, hoping subsidies from the EU funds as a member state to liquidate their aged plantations. In our opinion, this is not realistic in today's financial background that either the national budget or the EU funds want or are capable of financing 15-20 millions HUF in order to liquidate $15,000-20,000$ hectares of plantations in Hungary. At the right moment when farmers awake to it, they will quit, speeding up the liquidation of aged plantations.

There are also other reasons amplifying that tendency, which basically originates in the economic efficiency of apple production. According to Kiss (2003b) from the aspect of competitiveness in the apple industry, it would be wise to form the distribution of variety groups by harvest time into summer varieties, autumn varieties, and winter varieties with shares of $5 \%$, $40 \%$ and $55 \%$, respectively. To form such a structure of varieties, we have to put an end to aged plantations. Moreover, produce with poor quality that comes out of aged plantations have bad effects on the market. This is justified by Bodnár et al. (2005) who stated that apples that come out of those plantations with unfavourable structure of varieties, throw off the market balance, making a bad market situation for apples with good quality.

\section{References}

Bodnár, J. (2005): Almastratégia. Alma Terméktanács. Újfehértó, 3. p.

Ellinger, W. (2003): Der Markt für Obst und Gemüse. Agrarwirtschaft. Heft 1: 79-82.

Erdészné, (2000): A hazai gyümölcstermesztés utóbbi tiz éve. Kertészet és Szölészet. 24: 6-7.

Gonda, I. (2000): Az almatermesztés nemzetközi és hazai helyzete. In: Minöségi almatermesztés. (Szerk. Gonda I.) Nyiregyháza, Primom, 17. p.

KSH-Central Statistical Office (2001): Gyümölcsültetvények Magyarországon. KSH. Budapest, 170-173., 242-245.

Marosán, GY. (2001): Stratégiai menedzsment. Müszaki Könyvkiadó. Budapest, 106-117.

Pethö, F. (2006): Mi lesz veled Magyar Alma?! - Interactive szaktanácsadási nap. (Szerk: Gonda 1.) Debreceni Egyetem Agrártudományi Centrum. Debrecen, 79. p.

Saure, M. (2001): Apfelanbau in China - die große Bedrohung? Obstbau. 2. 95.p.

Szabó, T. (2006): Mi lesz veled magyar alma?! - Interaktiv szaktanácsadási nap. (Szerk: Gonda I.) Debreceni Egyetem Agrártudományi Centrum. Debrecen, 86-87.

Z. Kiss, L. (2003a): A gyümölcstermesztés feltételrendszere. In.: A gyümölcstermesztés, -tárolás, -értékesités szervezése és ökonómiája. (Szerk.: Z. Kiss). Mezögazda Kiadó. Budapest, 13. p.

Z. Kiss, L. (2003b): Az almatermesztés fejlesztése. In.: Kertészeti ágazatok szervezése és ökonómiája. (Szerk.: Magda S.). Szaktudás Kiadó. Budapest, 97, p. 